\title{
Book Review: The Soft Voice of Reason
}

Emanuel E. Garcia, MD

Institute of Pennsylvania Hospital, Philadelphia

Follow this and additional works at: https://jdc.jefferson.edu/jeffjpsychiatry

Part of the Psychiatry Commons

Let us know how access to this document benefits you

\section{Recommended Citation}

Garcia, MD, Emanuel E. (1987) "Book Review: The Soft Voice of Reason," Jefferson Journal of Psychiatry. Vol. 5 : Iss. 2 , Article 15.

DOI: https://doi.org/10.29046/JJP.005.2.014

Available at: https://jdc.jefferson.edu/jeffjpsychiatry/vol5/iss2/15

This Article is brought to you for free and open access by the Jefferson Digital Commons. The Jefferson Digital Commons is a service of Thomas Jefferson University's Center for Teaching and Learning (CTL). The Commons is a showcase for Jefferson books and journals, peer-reviewed scholarly publications, unique historical collections from the University archives, and teaching tools. The Jefferson Digital Commons allows researchers and interested readers anywhere in the world to learn about and keep up to date with Jefferson scholarship. This article has been accepted for inclusion in Jefferson Journal of Psychiatry by an authorized administrator of the Jefferson Digital Commons. For more information, please contact: JeffersonDigitalCommons@jefferson.edu. 


\title{
The Soft Voice of Reason
}

\author{
FREUD AS AN EXPERT WITNESS \\ K. R. Eissler \\ Madison, Connecticut, International Universities Press \\ 1986, 449 pages
}

\section{Emanuel E. Garcia, M.D.}

On December 19, 1918, after the devastation wrought by the First World War, Austria's provisional National Assembly responded to the outcries of its exhausted, angry and desperate populace by enacting legislation initiating the investigation of wartime derelictions of military duty. A commission was created and empowered to determine whether high-ranking military personnel had committed violations of law which warranted the institution of judicial proceedings. Almost immediately, the army medical services came under attack. Professor Wagner-Jauregg's psychiatric clinic in Vienna was singled out by Lt. Walter Kauders, who brought forth accusations of gross maltreatment. Julius WagnerJauregg, who had been appointed to the commission's panel at the time of its inception, suddenly found himself the object of its inquiries. The commission's chairman, Professor Loeffler, called upon Sigmund Freud to provide expert testimony for the investigation into Wagner-Jauregg's wartime conduct as a psychiatrist.

The ramifications of the confrontation between Freud, founder of a discipline either reviled or ignored by most psychiatrists of the day, and Wagner-Jauregg, popular and prestigious representative of academic psychiatry and future recipient of the Nobel Prize, ${ }^{1}$ form the subject of Eissler's masterful historical inquiry in Freud as an Expert Witness. The meeting between Freud and Wagner-Jauregg brought into relief two vastly different conceptions of man. On the one hand, was psychoanalysis, which envisioned man as a suffering animal, fraught with internal psychological conflicts, and buffeted by the hardships of an indifferent universe; on the other hand was classical academic psychiatry, which scorned the distinction between the conscious and unconscious realms of the mind, and sanctioned inherently cruel attitudes and practices in its quest for exactitude in the description, classification, and treatment of mental disorders.

Dr. Garcia is a second-year resident at the Institute of Pennsylvania Hospital, Philadelphia, Pennsylvania.

${ }^{1}$ Wagner-Jauregg was awarded the Nobel Prize in 1928 for his discovery of the malaria-cure for general paralysis of the insane. 
Eissler devotes a significant portion of his book to a biography of the man who instigated the fateful confrontation, demonstrating thereby the human impact of the theoretical issues at stake. Thus, a recapitulation of the major events of Kauders' course is necessary.

Walter Kauders was born in Vienna in 1889. At the outbreak of the war he was living in Switzerland with every opportunity to enjoy a safe haven from the war in favorable economic circumstances. Instead, he volunteered his services for the Austrian army. He came to experience firsthand not only the traumatic hazards of combat, but also the unforgivable lack of preparation and ineptitude of the Austrian forces. In September of 1914 he sustained a concussion in the field after a shell exploded nearby. An initial x-ray revealed a partial skull fracture, and raised the suspicion of a hematoma. Kauders experienced headaches, nausea, dysequilibrium and visual disturbances; he was declared unfit for duty. He continued to suffer these disabling symptoms and in August 1917 was referred to Germany's premier neurologist, Professor Erb, who diagnosed a partial fracture of the left parietal bone with possible pachymeningitis chronica or cyst. Later in 1917 Kauders was called before a military board for reevaluation of fitness for service, after which he was immediately ordered to WagnerJauregg's clinic.

At the clinic, Kauders was placed in solitary confinement for 77 days, and subjected to a form of electrotherapy called faradization on two occasions. Hygiene there was atrocious and scenes of brutality abundant. To his horror, Kauders witnessed the extreme sadism of one of Wagner-Jauregg's assistants, Dr. Michael Kozlowski, who used the faradic apparatus as a means of torture, on occasions applying the electrode brush to the exquisitely sensitive tips of fingers, toes, to the nipples and even the testicles. Kauders himself, like many at the overcrowded clinic, was branded a malingerer by Wagner-Jauregg. The formal charges, instigated by Kauders and taken up by the commission, concerned: 1) the harmful effects of electrotherapy; 2) the misuse of solitary confinement, and the cruel and inappropriate administration of emetics and other foul substances; and 3) the general strategy of torture, masquerading as treatment, whose sole purpose was returning as many soldiers as possible to the front.

Freud was first asked to submit written testimony, which he did in the form of a beautifully composed, lucid memorandum on the treatment of war neuroses, reprinted in full for the reader's convenience (1). In it, the major themes that would arise during the verbal testimony were given their first airing. He described the "war neuroses"-typically, motor disturbances such as tremors and paralyses which resulted from the traumatic shock of combat - and identified their immediate cause in the unconscious desire of the patients to withdraw from the demands of the service. Malingering, he asserted, was rare. He of course considered it an error to ignore the difference between conscious and unconscious intention, a consequence of which would be to treat war neurotics as malingerers. He exposed the real purpose of electrotherapy as merely providing a painful counterstimulus that would cause the soldier to flee 
back to the front, its primary aim assuredly not the restoration of the patient's psychological health. Furthermore, he drew attention to the great dangers of practicing medicine in such a way that the fundamental claims of humanity and service to the individual would be sacrificed for pragmatic concerns, e.g., the demands of war and national purpose. Finally, Freud noted how modifications of his psychoanalytic technique had been employed successfully in the treatment of severe war neuroses by Dr. Ernst Simmel.

The commission's hearing, the pertinent portions of which Eissler reproduces from the available transcripts, lasted two days. Freud testified only on the first. He gave the opinion that Kauders probably suffered from an acute traumatic neurosis which was, as it were, grafted onto a cerebral injury. Freud, who trained initially as a neurologist, drew attention to a part of Kauders's medical history documenting a slowing of the pulse, which he interpreted as a probable indication of the presence of an organic cerebral lesion-a notion dismissed altogether by Wagner-Jauregg. Freud flatly declared the use of electrotherapy inappropriate and stressed his belief that Kauders was not a malingerer. On these points he was at loggerheads with Wagner-Jauregg, who defended his clinic's treatment, citing the harmlessness and success of electrotherapy, and who vehemently denounced Kauders as a dodger, refusing to concede the existence of either an organic lesion or an unconsciously motivated traumatic neurosis. Clearly his concept of neurosis was a far cry from Freud's, as can be shown by his veritable equation of neuroses and malingering on the basis of the "imaginary" nature of the physical complaints. Despite his basic scientific disagreements with Wagner-Jauregg, Freud nevertheless was convinced of the latter's personal integrity and honesty of purpose.

On the second day of the hearing, in Freud's absence, psychoanalysis was subjected to a vicious, ill-founded and gratuitous attack by Wagner-Jauregg's followers. Glowing testimonials to Wagner-Jauregg's brilliance and self-sacrifice during a most arduous period were given, and in the end Wagner-Jauregg emerged fully rehabilitated and professionally unscathed.

In addition, however, evidence that abuses had been carried out at the clinic, presumably without Wagner-Jauregg's knowledge, was brought forward. Accusations against Dr. Michael Kozlowski alleged that faradization became a means of sadistic torture in his hands. Furthermore, from the testimony of Prof. Arnold Durig, who held no overt bias for or against electrotherapy, we are able to learn not only that these accusations were well-founded, but that electrotherapy was actually a gross treatment failure. Durig also revealed that war neurotics had indeed been returned to the front, albeit against Wagner-Jauregg's intentions.

In Eissler's estimation, the result of exhaustive and scrupulous research in the service of historical reconstruction, Wagner-Jauregg is neither villain nor hero. There is no question that Wagner-Jauregg was inadequate to the task he faced during the war, not to say negligent of duty, if the individual's health is 
understood as a physician's primary responsibility. In the case of Kauders, for example, it becomes clear that no attempt to elicit a decent psychiatric history, the work of a mere hour, was ever made. If it had been, it would assuredly have proved inconceivable to brand a man like Kauders a malingerer. But this was ultimately a reflection of the inadequacy and negligence of classical psychiatry at the time, which must be seen in historical perspective. After all, the approach of the classical psychiatrist, as woefully impotent in the treatment of mental disorders, and as replete with cruelties as it was, nevertheless led to a detailed description and classification of the disorders. Thus it fulfilled an essential and valuable service that helped to pave the way for the next great advance, namely, the Freudian revolution.

Such a brief outline as this does little justice to the richness of Eissler's method, the multiplicity of his insights, or his keen understanding of the great social forces forming the backdrop against which the drama between Freud and Wagner-Jauregg was played. Eissler presents not only a detailed historical account of the war neuroses and the evolution of their treatment, but a fascinating life history of Kauders as well, based on data from his own personal interviews with the man. He also discusses the important problem of malingering at considerable length, drawing on his own experience as a psychiatrist in the U.S. Army during World War II. Eissler clearly identifies the central role of the psychiatrist's subjective attitude in the diagnosis of malingering, and provides evidence to support the concept of true malingering as an illness itself, "which in reality is the result of a seriously deranged and permanently defective personality" (p. 275) — not the con-job of a wily and psychologically whole manipulator. ${ }^{2}$

Eissler's work is a beautiful example of historical investigation, and it should be required reading for all concerned with the psychology of man. Interestingly enough, and not unexpectedly, one need not look far to perceive parallels in our own era. The ascendancy of the biological psychiatrist, with his emphasis on the chemical basis of behavior and thought, carries the danger that the approaches of Wagner-Jauregg and Kraepelin will be revived, marked by their tacit assumption of the incomparable superiority of the psychiatrist to the patient, and ignorance-or disavowal — of the psychology of the unconscious.

Paradoxically enough, one of the great humanistic movements in history, psychoanalysis, now finds itself criticized-by feminists, Marxists, historians, sociologists and psychiatrists, among others-for its ostensibly oppressive influences. Perhaps the bureaucratization of the profession of psychoanalysis and the inevitable perversions of the discipline have deflected attention from the historical truths about Freud's science. And perhaps those analysts who have

\footnotetext{
${ }^{2}$ This definition excludes those who, like physicist Leopold Infeld, feigned illness for idealistic purposes. As a soldier in the Austro-Hungarian Army, Infeld set out to do all he could to bring about defeat for Germany and Austria.
} 
gone on record supporting the death penalty, condemning homosexuality, or excluding nonmedical people from analytic training, views which Freud himself abhorred, have forgotten their roots. For them Eissler's magnificent book should serve as a much-needed reminder.

\section{REFERENCE}

1. Freud S: Memorandum on the electrical treatment of war neurotics. Standard Edition, 17:211-215, 1955 